\title{
ÉTICA COMO NECESSIDADE ${ }^{1}$
}

\author{
Sérgio Marcos de Moraes Pitombo \\ Professor Doutor do Departamento de Direito Processual \\ da Faculdade de Direito da Universidade de São Paulo
}

Queridos alunos:

É costume ao término de sua fala o paraninfo cumprimentar-lhes as famílias e lhes desejar muito bom êxito, no correr da vida profissional. Apresso-me a fazê-lo logo. Saúdo-as; e a todos os formandos quero ver bem-sucedidos.

Peço, entretanto, que atentem, sempre, para a maneira de ser e de proceder, como advogados, delegados de Polícia, promotores de Justiça, juízes de Direito, legisladores, ou como administradores públicos.

Nenhuma profissão se exerce com dignidade, no abandono do comportamento ético. Tal afirmação pela evidência mostrar-se-ia desútil não fora os tempos.

O Estado - dizia-se, secularmente era uma empresa do povo. Hoje percebe-se - tornou-se de alguns, assumindo afeiçoamento quase privado.

O pleno descompromisso com a verdade exibe-se qual destreza política, em só construí-la em vez de desvendá-la. A mentira converteu-se, assim, em elemento prevalente de estratégias eleitorais e de governos. E, o significado das palavras falsea-se. A mais atormentante agiotagem recebe a denominação de instrumento de política econômica. A alucinação tributária apresenta-se como meio razoável de atingir a Justiça social. O desamparo - ainda exemplificando - das cidades vida urbana e paz pública - ostenta-se como dever descumprido, porém, de toda a comunhão social; e, tão-só, cóntingente responsabilidade dos governantes.

A legislação descuidada, assistemática e contraditória serve ao imediato, à situação emergente. Muita vez, despontando a toque de imprensa; como vem sucedendo no Direito e no processo penal. Atendem-se às aparências; mas, se acha perdendo o sentido comum de torto e de direito. 
A Justiça falha, algumas vezes, seja em virtude da burocultura judiciária; seja pela resistência insuficiente ao cortesanismo. Na base da desfunção, acha-se o entorpecimento da igualdade.

Senhores formandos: nestas derradeiras e breves palavras de professor, concito-os a questionar, durante a existência, sobre o valor, que os levará; ou que os conduziu a agir, nos diversos lanços da profissão. Animo-os a meditar na dimensão pessoal da conduta, a partir-lhe do motivo ético. Desnecessário lembrarlhes de que nenhum juízo ético importa, se não serve para orientar a vida prática.

Aguardo, pois, que o bom êxito, o sucesso, antes desejado, concretizese no arredamento da angústia moral e na construção de um Brasil melhor e mais justo.

São Paulo, 10 de dezembro de 1997. 